Hijawati, Peredaran Obat Illegal Ditinjau Dari Hukum Perlindungan Konsumen, Halaman 394-406

\title{
PEREDARAN OBAT ILLEGAL DITINJAU DARI HUKUM PERLINDUNGAN KONSUMEN
}

\author{
Hijawati \\ Fakultas Hukum Universitas Palembang \\ E-mail: hijawati@unpal.ac.id
}

\begin{abstract}
Every person has the right to live a healthy life, various efforts or methods if someone is sick and wants to deal with his complaint or illness with various medicines in order to recover his condition. In the era of globalization, free trade occurs which results in goods and or services in circulation that do not guarantee the security, safety and health of consumers. The free circulation of illegal drugs is still in demand by some consumers, this is because these drugs are easy to obtain and sell freely at any drug store. Law Number 8 of 1999 concerning Consumer Protection, the Government of Indonesia regulates consumer rights that must be protected. In the Consumer Protection Act, it provides appreciation for consumer rights universally, because consumer protection is part of protecting human rights.
\end{abstract}

Keywords: consumer protection; illegal drugs

Abstrak

Setiap orang memiliki hak hidup sehat, berbagai upaya atau cara apabila seseorang sakit berkeinginan mengatasi keluhan atau sakitnya dengan berbagai macam obat agar dapat pulih keadaannya. Era globalisasi terjadi perdagangan bebas yang mengakibatkan barang dan atau jasa yang beredar belum tentu terjamin keamanan, keselamatan dan kesehatan konsumen. Bebasnya peredaran obat-obatan illegal masih diminati sebagian konsumen, ini disebabkan karena obat-obatan tersebut mudah di dapat dan di jual bebas pada setiap toko obat yang ada. Undang-undang Nomor 8 Tahun 1999 tentang Perlindungan Konsumen, Pemerintah Indonesia mengatur hak-hak konsumen yang harus dilindungi. Dalam Undang-Undang Perlindungan konsumen memberikan apresiasi terhadap hak-hak konsumen secara universal, karena perlindungan konsumen adalah bagian dari perlindungan hak asasi manusia.

Kata Kunci: perlindungan konsumen; obat illegal

\section{PENDAHULUAN}

Kesehatan merupakan salah satu modal untuk berlangsungnya kehidupan manusia, produktivitas dan aktivitas seseorang dipengaruhi oleh kondisi kesehatan orang tersebut. Kesehatan merupakan keadaan sejahtera dari badan, jiwa, dan sosial yang memungkinkan setiap orang hidup produktif secara sosial dan ekonomis.
Berdasarkan penjelasan dalam Undang-Undang Nomor 36 Tahun 2009 tentang Kesehatan, maka kesehatan merupakan hak asasi manusia dan salah satu unsur kesejahteraan yang harus diwujudkan sesuai dengan cita-cita bangsa Indonesia sebagaimana dimaksud dalam Pancasila dan Pembukaan Undang- Undang Dasar Negara Republik Indonesia Tahun 1945. 
Hijawati, Peredaran Obat Illegal Ditinjau Dari Hukum Perlindungan Konsumen, Halaman 394-406

Kesehatan sangat memberikan pengaruh yang besar dalam semua sektor kehidupan, karena tujuan dari pemerintah dalam pelaksanaan pemeliharaan kesehatan adalah mencapai derajat kesehatan baik individu maupun masyarakat secara optimal. ${ }^{1}$ Keberhasilan upaya kesehatan ini tergantung pada ketersediaan sumber daya kesehatan yang berupa tenaga, sarana, dan prasarana dalam jumlah dan mutu yang memadai. ${ }^{2}$ Setiap orang pasti mengingkan hidup sehat, dan dengan berbagai upaya atau cara apabila seseorang sakit ingin cepat mengatasi keluhan atau sakitnya dengan berbagai macam obat agar dapat cepat memulihkan keadaannya. Terkadang ada juga sebagian dari orang agar tetap terlihat tampil cantik rela mengorbankan uang untuk dapat memperoleh kecantikannya tersebut dengan menggunakan berbagai macam obat. Perekonomian merupakan sektor yang sangat penting untuk berlangsungnya perekonomian yang baik adalah konsumen. Hal tersebut dikarenakan konsumen mempunyai posisi sebagai objek bisnis yang dapat dijadikan ladang

\footnotetext{
${ }^{1}$ Wila Chandrawila Supriadi, Hukum Kedokteran (Bandung: Mandar Maju, 2001).

${ }^{2}$ Sri Praptianingsih, Kedudukan Hukum perawat Dalam Upaya Pelayanan Kesehatan di Rumah Sakit (Jakarta: Raja Grafindo Persada, 2006).
}

untuk keuntungan sebesar-besarnya. Kenyataannnya pada saat ini sudah banyak sekali produsen yang muncul dengan produk barang atau jasa yang sangat bersaing di pasar, mereka berlomba-lomba untuk menarik perhatian konsumen agar memperoleh penjualan yang tinggi sehingga mendapatkan laba yang tinggi pula.

Dalam Era globalisasi ini dimana perdagangan bebas cenderung mengakibatkan barang dan atau jasa yang beredar belum tentu menjamin keamanan, keselamatan dan kesehatan konsumen, terlebih lagi mengingat keadaan konsumen yang rata-rata kurang bersikap hati-hati, kondisi tersebut dikarenakan posisi pihak konsumen berada di pihak yang lemah dalam menghadapi pihak produsen. Keadaan yang seperti ini, dapat mengakibatkan kedudukan dari konsumen dan pelaku usaha menjadi tidak seimbang. Di mana dalam hal ini, kedudukan konsumen berada dalam posisi yang lemah. Konsumen hanya menjadi objek aktivitas bisnis untuk meraup keuntungan yang sebesar-besarnya oleh pelaku usaha, serta banyaknya produsen yang bersaing dalam meraup untung dari para konsumen, sehingga tidak sedikit dari mereka yang melakukan kecurangan 
Hijawati, Peredaran Obat Illegal Ditinjau Dari Hukum Perlindungan Konsumen, Halaman 394-406

untuk hal itu. Dari hal kecurangan yang mereka lakukan bisa dari segi promosi, penjualan atau penerapan perjanjian standar yang merugikan konsumen. ${ }^{3}$ Sehingga pemberlakuan undang-undang ini diharapkan dapat menjadi landasan bagi konsumen dan lembaga perlindungan konsumen untuk memberdayakan dan melindungi kepentingan konsumen, menanggapi hal itu pemerintah Indonesia telah mengesahkan Undang-undang tentang perlindungan konsumen, agar dapat membuat pelaku usaha lebih bertanggung jawab. Adapun tujuan dari undang-undang ini adalah untuk melindungi hak-hak konsumen, yaitu: hak atas keyamanan, keamanan, dan keselamatan dalam mengkonsumsi barang dan/atau jasa. Undang- Undang Nomor 8 Tahun 1999 tentang Perlindungan Konsumen, diharapkan dapat menjamin tercapainya penyelenggaraan perlindungan

konsumen di masyarakat.

Pada prakteknya peran pemerintahan di Indonesia masih kurang dalam menegakan undang-undang perlindungan konsumen ini, terbukti walaupun telah disahkannya undang-

\footnotetext{
${ }^{3}$ Gunawan Wijaya dan Ahmad Yani, Hukum Perlindungan Konsumen (Jakarta: PT. Gramedia Pustaka Utama, 2003).
}

undang tentang perlindungan terhadap konsumen, tetapi tetap saja dalam prakteknya masih banyak sekali kasuskasus dalam perdagangan yang sangat merugikan konsumen. Pada saat ini penegakan undang-undang perlindungan konsumen terutama dalam hal pengawasan terhadap barang beredar yang dilakukan oleh pemerintah masih kurang. Contohnya saja produk-produk kadaluarsa yang beredar di pasaran. Keberadaan zat kimia berbahaya yang terjual dan beredar bebas di supermarket dan pasar tradisional. Dan hal ini sangat memudahkan para produsen-produsen nakal yang ingin meraup keuntungan lebih dengan cara menipu para konsumen dengan cara membuat atau menggunakan zat-zat kimia berbahaya seperti boraks, formalin, dan zat pewarna tekstil untuk bahan makanan yang dijualnya.

Sebenarnya karena faktor kurangnya pengawasan terhadap para pelaku usaha yang berlaku curang, mereka tidak pernah memikirkan dampak dari ulahnya tersebut, mereka hanya memikirkan kepentingannya semata tanpa memikirkan dampak bagi orang lain. Dan di sisi lain masyarakat juga mudah sekali tertipu oleh produk tiruan yang justru kualitasnya jauh dari 
Hijawati, Peredaran Obat Illegal Ditinjau Dari Hukum Perlindungan Konsumen, Halaman 394-406

produk yang asli. Padahal hal ini sangat membahayakan karena obat dan makanan illegal tersebut berhubungan langsung dengan kesehatan tubuh. Akan tetapi justru produk yang menggunakan bahan-bahan berbahaya tersebut mudah sekali kita jumpai di sekitar kita. Disamping itu juga, produk jasa yang ada selama ini juga banyak yang merugikan konsumen. Melihat hal ini seharusnya Pemerintah lebih tegas dalam melindungi konsumen, akan tetapi sampai saat ini kepedulian Pemerintah masih sangat kurang.

Bebasnya peredaran obat-obatan illegal ternyata banyak diminati konsumen, ini disebabkan karena obatobatan tersebut mudah di dapat dan di jual bebas pada setiap toko obat yang ada. Karena pada sisi lain sebenarnya harus ada pengawasan yang dilakukan oleh pemerintah, pengawasan ini dimaksudkan agar proses perizinannya berfungsi preventif serta tidak akan merugikan konsumen. Sekarang banyak aparat penegak hukum yang berwenang seakan tidak tahu atau pura-pura tidak tahu bahwa dalam dunia perdagangan atau dunia pasar terlalu banyak para pelaku usaha yang jelas-jelas telah melanggar Undang-Undang
Perlindungan Konsumen dan merugikan kepentingan konsumen.

Perlindungan konsumen bukan hanya tugas pemerintah, tapi juga pengusaha ikut andil dalam melindungi konsumen. Di sini pemerintah berperan dalam membentuk peraturan dan penegakan hukum melalui berbagai aktivitas pengawasan barang. Namun, pelaku usaha juga berperan penting untuk berkomitmen pada aturan perlindungan konsumen. Undangundang perlindungan konsumen tidak dapat berjalan hanya dengan mengandalkan peran pemerintah dalam membentuk peraturan dan penegakan hukum melalui berbagai aktivitas pengawasan barang. Tetapi ini saatnya pelaku usaha sebagai "sahabat" pemerintah mampu berperan serta dalam menegakkan perlindungan konsumen.

Penulisan ini berkaitan dengan perlindungan konsumen pada produk obat illegal. Dalam penulisan ini jenis penelitian yang digunakan adalah jenis penelitian yuridis normatif, yaitu penelitian yang dilakukan pada peraturan-peraturan yang berkaitan dengan masalah pemalsuan obat yang illegal ditinjau dari Undang-Undang Perlindungan Konsumen. 
Hijawati, Peredaran Obat Illegal Ditinjau Dari Hukum Perlindungan Konsumen, Halaman 394-406

\section{PEMBAHASAN}

Berdasarkan Undang-Undang Nomor 36 Tahun 2009 Tentang Kesehatan, maka obat adalah bahan atau paduan bahan, termasuk produk biologi yang digunakan untuk mempengaruhi atau menyelidiki sistem fisiologi atau keadaan patologi dalam rangka penetapan diagnosis, pencegahan, penyembuhan, pemulihan, peningkatan kesehatan dan kontrasepsi, untuk manusia.

Obat illegal adalah obat impor yang tidak terdaftar di Badan POM sehingga tidak mempunyai izin edar di Indonesia. Informasi di labelnya harus dalam Bahasa Indonesia, karena bila dalam bahasa asing berarti illegal. Dalam obat illegal dilarang diedarkan dan diberikan kepada pasien.

Menurut KepMenKes No. 1010 / 2000: Obat palsu adalah obat yang diproduksi oleh yang tidak berhak berdasarkan peraturan per-undang undangan yang berlaku dengan penandaan yang meniru identitas obat lain yang telah memiliki izin edar. Obat palsu menurut WHO (World Health Organization) terbagi dalam 5 kelompok, yaitu :

1. Produk obat tanpa zat aktif (API = Active Pharmaceutical
Ingredient). Contohnya: Obat Chloramfenicol diganti dengan gula Lactose .

2. Produk dengan kandungan zat aktif kurang dari yang tercantum pada label/etiket/kemasannya. Contohnya : Chloramfenicol $250 \mathrm{mg}$ isinya hanya $100 \mathrm{mg}$.

3. Produk dengan zat aktif yang berbeda. Contohnya : Obat Chloramfenicol diganti dengan pil kina.

4. Produk yang diproduksi dengan menjiplak produk milik pihak lain.

5. Produk dengan kadar zat aktif yang sama tetapi menggunakan label dengan nama produsen atau negara asal berbeda.

Di Indonesia beredar obat palsu kelompok lain yaitu: Produknya produk pabrik asli hanya saja produknya sudah expired (kadaluwarsa) dimana etiket/ hologram dan lainnya, diganti, ditempel dengan buatan etiket/ hologram yang baru dengan E.D. yang baru.

Perlu diketahui masyarakat tentang obat yang sering dipalsukan adalah obat yang paling laku dipasaran yaitu:

Antibiotika-AnalgetikaAntihistaminika dan obat-obat untuk penyakit degeneratif seperti, obat penyakit tekanan darah tinggi, obat penyakit kencing manis.

Pada banyaknya kasus yang terkait dengan pelanggaran terhadap peredaran obat dan makanan di 
Hijawati, Peredaran Obat Illegal Ditinjau Dari Hukum Perlindungan Konsumen, Halaman 394-406

Indonesia, seperti pemakaian bahan mendorong konsumen untuk pengawet formalin, susu formula mengkonsumsi secara berlebihan dan berbakteri, kosmetika palsu, ataupun peredaran obat (juga jamu) palsu. Bahkan hanya $2 \%$ dari produk buatan China yg terdaftar. Berbagai kasus itu mengindikasikan bahwa masih lemahnya sistem pengawasan obat dan makanan di Indonesia, padahal konsumsi masyarakat terhadap produk obat, makanan, kosmetika, alat kesehatan, dan obat asli Indonesia cenderung meningkat.

Sebagian konsumen tidak memiliki pengetahuan yang memadai tentang produk yang dikonsumsinya itu, apakah sudah tepat, benar, dan aman. Karena itu, Indonesia memerlukan sistem pengawasan obat dan makanan yang efektif dan mampu mendeteksi, mencegah serta mengawasi produkproduk guna melindungi keamanan, keselamatan, dan kesehatan konsumen.

Komsumsi masyarakat terhadap produk obat dan makanan illegal cenderung meningkat, seiring dengan perubahan gaya hidup masyarakat termasuk pola komsumsinya. Sementara itu pengetahuan masyarakat masih belum memadai untuk dapat memilih dan menggunakan produk secara tepat, benar dan aman tersebut. Di lain pihak iklan dan promosi secara gencar sering kali tidak rasional. Perubahan teknologi produksi, sistem perdagangan internasional dan gaya hidup konsumen tersebut pada realitasnya meningkatkan resiko dengan implikasi yang luas pada kesehatan dan keselamatan konsumen.

Masyarakat pada umumnya kurang memahami akibat yang bisa ditimbulkan dari pemakaian atau penggunaan obat illegal, hal ini dikarenakan karena mereka tidak mengerti serta kurang memahami kandungan yang terdapat dalam obatobatan illegal tersebut. Kerugian yang ditimbulkan akibat pemakain obat illegal/palsu yaitu :

1. Bagi pasien yang memerlukan pengobatan jangka panjang, obat illegal/palsu bisa berakibat sasaran pengobatan tidak tercapai. Misalnya saja, suatu obat dalam data statistik disebutkan bisa mengurangi serangan jantung sampai 25 persen atau mengurangi kemungkinan stroke hingga 30 persen. Namun, karena adanya penggunaan obat palsu, rentang persen tersebut tidak tercapai. 
Hijawati, Peredaran Obat Illegal Ditinjau Dari Hukum Perlindungan Konsumen, Halaman 394-406

2. Pada kasus penggunaan antibiotika palsu menyebabkan terjadinya resistensi.

3. Obat palsu juga bisa menimbulkan penyakit lain pada pasien, misalnya alergi.

4. Dan yang paling fatal, obat palsu juga bisa merenggut nyawa.

5. Menyebabkan kerugian materi pada konsumen

Pemerintah melalui Keppres Nomor 166 Tahun 2000 dan Nomor 103 Tahun 2001 membentuk Badan Pengawas Obat dan Makanan (BPOM) yang bertugas, antara lain memberi izin dan mengawasi peredaran obat serta pengawasan industri farmasi. Karena sejauh ini pendaftaran makanan dan minuman untuk seluruh wilayah Indonesia ditangani langsung oleh Direktorat Penilaian Keamanan Pangan,

Badan POM selaku badan yang memiliki otoritas didalam pengawasan obat dan makanan di Indonesia, terus berupaya untuk memenuhi keinginan masyarakat dengan meningkatkan perannya didalam melindungi masyarakat dari peredaran obat tradisional yang tidak memenuhi syarat mutu dan keamanan. Disamping itu Badan POM juga berperan dalam membina industri maupun importir/distributor secara komprehensif mulai dari pembuatan, peredaran serta distribusi, agar masyarakat terhindar dari penggunaan obat tradisional yang berisiko bagi pemeliharaan kesehatan Pengawasan yang dilakukan oleh Badan POM dimulai sebelum produk beredar yaitu dengan evaluasi produk pada saat pendaftaran (pre marketing evaluation/product safety evaluation), inspeksi sarana produksi sampai kepada pengawasan produk di peredaran (post marketing surveillance).

Sebagai salah satu pilar Sistem Pengawasan Obat dan Makanan (SISPOM), pelaku usaha mempunyai peran yang sangat strategis. Pelaku usaha harus bertanggungjawab dalam pemenuhan standar dan persyaratan sesuai dengan ketentuan yang berlaku terkait dengan produksi dan distribusi Obat dan Makanan sehingga menjamin Obat dan Makanan yang diproduksi dan diedarkan aman, berkhasiat/bermanfaat, dan bermutu. ${ }^{4}$

Peredaran obat illegal/palsu/substandard hingga kini masih ada. Bahkan ada obat yang masuk secara jalur resmi seperti Toko Obat Berijin, PBF, Apotek, Rumah Sakit, bahkan Pabrik Farmasi. Oleh karena itu

${ }^{4}$ https://www.pom.go.id/new/admin/dat/2019070 8/Direktorat_Pengamanan.pdf, 2020. 
Hijawati, Peredaran Obat Illegal Ditinjau Dari Hukum Perlindungan Konsumen, Halaman 394-406

tugas Pengawasan dan Pemberantasan Obat Ilegal/palsu/substandar tidak hanya dibebankan oleh BPOM saja tetapi harus melibatkan seluruh institusi terkait dan masyarakat.

Pasal 98 dalam Undang-Undang Kesehatan terhadap peraturan pada pelaku usaha penyedia obat berkaitan dengan farmasi dan alat kesehatan harus aman, berkhasiat/bermanfaat, bermutu, dan terjangkau. Setiap orang yang tidak memiliki keahlian dan kewenangan dilarang mengadakan, menyimpan, mengolah, mempromosikan, dan mengedarkan obat dan bahan yang berkhasiat obat. Ketentuan mengenai pengadaan, penyimpanan, pengolahan, promosi, pengedaran sediaan farmasi dan alat kesehatan harus memenuhi standar mutu pelayanan farmasi yang ditetapkan dengan Peraturan Pemerintah. Pemerintah berkewajiban membina, mengatur, mengendalikan, dan mengawasi pengadaan, penyimpanan, promosi, dan pengedaran sebagaimana dimaksud.

Sanksi pemalsuan obat menurut pasal 62 Undang-undang Perlindungan Konsumen Tahun 1999 cukup berat. Pelaku usaha jika terkait obat ilegal dapat diancam pidana maksimal lima tahun dan denda Rp 2 milyar.

Sedangkan sanksi pelaku dalam Undang-Undang Nomor 36 Tahun 2009 tentang Kesehatan adalah dalam Pasal 196, menyatakan bahwa Setiap orang yang dengan sengaja memproduksi atau mengedarkan sediaan farmasi dan/atau alat kesehatan yang tidak memenuhi standar dan/atau persyaratan keamanan, khasiat atau kemanfaatan, dan mutu sebagaimana dimaksud dalam Pasal 98 ayat (2) dan ayat (3) dipidana dengan pidana penjara paling lama 10 (sepuluh) tahun dan denda paling banyak Rp1.000.000.000,00 (satu miliar rupiah).

Pasal 197, menyatakan bahwa Setiap orang yang dengan sengaja memproduksi atau mengedarkan sediaan farmasi dan/atau alat kesehatan yang tidak memiliki izin edar sebagaimana dimaksud dalam Pasal 106 ayat (1) dipidana dengan pidana penjara paling lama 15 (lima belas) tahun dan denda paling banyak Rp1.500.000.000,00 (satu miliar lima ratus juta rupiah).

Pasal 198, bahwa Setiap orang yang tidak memiliki keahlian dan kewenangan untuk melakukan praktik kefarmasian sebagaimana dimaksud dalam Pasal 108 dipidana dengan pidana denda paling banyak Rp100.000.000,00 (seratus juta rupiah).

Peraturan Kepala Badan Pengawas Obat Dan Makanan Republik Indonesia Nomor Hk.00.05.1.3459 Tentang Pengawasan Pemasukan Obat Impor: 
Hijawati, Peredaran Obat Illegal Ditinjau Dari Hukum Perlindungan Konsumen, Halaman 394-406

1. Izin Edar adalah bentuk persetujuan registrasi obat untuk dapat diedarkan di wilayah Indonesia.

2. Obat Impor adalah obat produksi industri farmasi luar negeri.

3. Pemasukan obat impor adalah importasi obat impor ke dalam wilayah Indonesia baik melalui pelabuhan laut maupun bandar udara.

4. Pendaftar adalah Industri Farmasi atau Pedagang Besar Farmasi yang telah mendapat izin usaha sesuai ketentuan perundang-undangan yang berlaku.

Permenkes No.922/menkes/per/ $\mathrm{x} / 1993$ tentang ketentuan dan tata cara pemberian izin apotik, khususnya pada pasal 12 ayat 2 yang berbunyi: obat dan perbekalan farmasi lainnya yang karena suatu hal tidak dapat digunakan lagi atau dilarang digunakan, harus dimusnahkan dengan cara dibakar atau ditanam atau dengan cara lain yang ditetapkan Direktur Jenderal.

Dalam Undang-undang perlindungan konsumen, khususnya bab III pasal 4 mengenai hak konsumen, yaitu :

1. Hak atas kenyamanan, keamanan, dan keselamatan dalam mengkonsumsi barang dan/atau jasa;

2. Hak untuk memilih barang dan/atau jasa serta mendapatkan barang dan/atau jasa tersebut sesuai dengan nilai tukar dan kondisi serta jaminan yang dijanjikan;
3. Hak atas informasi yang benar, jelas, dan jujur mengenai kondisi dan jaminan barang dan/atau jasa;

4. Hak untuk didengar pendapat dan keluhannya atas barang dan/atau jasa yang digunakan;

5. Hak untuk diperlakukan atau dilayani secara benar dan jujur serta tidak diskriminatif;

6. Hak untuk mendapatkan kompensasi, ganti rugi dan/atau penggantian, apabila barang dan/atau jasa yang diterima tidak sesuai dengan perjanjian atau tidak sebagaimana mestinya.

Berdasarkan data perkara yang ditangani PPNS Badan POM periode tahun 2011 sampai 2017 dapat dikatakan bahwa jumlah perkara, jenis temuan, dan nilai ekonomi temuan cenderung terus mengalami peningkatan. Hal tersebut perlu menjadi perhatian yang serius mengingat bahwa peredaran produk Obat dan Makanan tanpa jaminan keamanan, manfaat, dan mutu, selain aspek pelanggaran administratif juga dapat membahayakan kesehatan masyarakat dan generasi penerus bangsa. Di samping itu produk ilegal juga juga berdampak terhadap ekonomi negara dan melemahkan daya saing bangsa. ${ }^{5}$

Peredaran obat palsu hingga kini masih terus terjadi, Yayasan Lembaga

${ }^{5}$ https://www.pom.go.id/new/admin/dat/2019070 8/Direktorat_Pengamanan.pdf, 2020. 
Hijawati, Peredaran Obat Illegal Ditinjau Dari Hukum Perlindungan Konsumen, Halaman 394-406

Konsumen Indonesia (YLKI) menilai maraknya peredaran obat-obat ilegal di tengah masyarakat disebabkan penegakan hukum terhadap pelaku obat ilegal masih sebatas dari sisi hilir, sehingga belum mampu membuat efek jera bagi pelaku. ${ }^{6}$

\section{Perlindungan Konsumen Terhadap Obat Illegal}

Dengan pesatnya perekonomian saat ini, telah menghasilkan beragam jenis dan variasi barang dan/atau jasa, termasuk juga pada barang-barang produk obat-obatan.

Hal ini sangat menguntungkan konsumen dengan berbagai ragam variatif barang dan/atau jasa yang ditawarkan. Tetapi kondisi ini menempatkan kedudukan konsumen terhadap produsen menjadi tidak seimbang, dimana konsumen menjadi objek aktiviats bisnis untuk meraup keuntungan yang besar. Dan ketidakberdayaan ini pada umumnnya karena produsen selalu berlindung di balik standard contract atau perjanjian baku yang telah disepakati oleh kedua belah pihak.

${ }^{6} \mathrm{https} / / /$ www.hukumonline.com/berita/baca/lt57d 1345b3ed21/4-sebab-peredaran-obat-ilegalmasih-marak/, 2020.
Pada hubungan produsen dan konsumen sejatinya merupakan hubungan timbal-balik, tetapi terkadang banyak sekali terjadi potensi akal-akalan oleh produsen yang akhirnya merugikan pihak konsumen. Untuk itulah sebagai seorang konsumen yang cerdas dan paham hukum, kita mempunyai hak dan kewajiban yang sudah diatur dalam undang-undang, yaitu Undang undang Perlindungan Konsumen.

Dalam perlindungan konsumen yang merupakan bagian dari kemajuan teknologi dan industri ternyata memperkuat perbedaan antara pola masyarakat tradisional maupun masyarakat modern. Sehingga masyarakat tradisional memproduksi barang-barang kebutuhan konsumen masih secara sederhana, dimana konsumen dan produsen bisa bertatap muka secara langsung, sedangkan masyarakat modern memproduksi barang-barang kebutuhan konsumen secara massal, sehingga hubungan anatara konsumen dan produsen menjadi rumit, dimana konsumen tidak mengenal siapa produsennya.

Perlindungan konsumen ini memiliki hubungan yang erat dengan globalisasi ekonomi, dengan konsekwensi bahwa semua barang yang 
Hijawati, Peredaran Obat Illegal Ditinjau Dari Hukum Perlindungan Konsumen, Halaman 394-406

berasal dari negara lain dapat masuk ke Indonesia, dimana barang tersebut tidak saja berkualitas rendah akan tetapi juga dapat membahayakan konsumen. Padahal sesungguhnya setiap perusahaan harus memiliki tanggung jawab sosial (corporate social responsibility), yaitu kepedulian moral perusahaan terhadap kepentingan masyarakat, terlepas dari untung atau rugi perusahaan.

Dalam pengaturan perlindungan konsumen tidak dimaksudkan untuk mematikan ataupun melemahkan usaha dan aktivitas pelaku usaha, tetapi justru diharapkan dapat mendorong iklim dan persaingan usaha yang sehat melalui penyediaan barang dan/atau jasa yang berkualitas. Dan sebelum tahun 1999, hukum positif Indonesia belum mengenal istilah konsumen, kendati demikian beberapa istilah yang berkaitan dengan konsumen tersebut mengacu kepada perlindungan konsumen, namun belum memiliki ketegasan dan kepastian hukum tentang hak-hak konsumen. Istilah konsumen berasal dari kata "consumer" yaitu sebagai pemakai barang-barang hasil industri, bahan makanan dan sebagainya. ${ }^{7}$ Undangundang Nomor 8 tahun 1999 tentang Perlindungan Konsumen menyebutkan

${ }^{7}$ WJS. Poerwadarminta, Kamus Umum Bahasa Indonesia (Jakarta: Balai Pustaka, 1999). konsumen adalah setiap orang yang memakai "barang dan/atau jasa" yang tersedia dalam masyarakat" baik bagi kepentingan diri sendiri, keluarga, orang lain maupun makhluk hidup lainnya dan tidak untuk diperdagangkan.

Pengertian konsumen dapat dibedakan dalam tiga batasan antara lain:

1. Konsumen komersial (commercial consummer), adalah setiap orang yang mendapatkan barang dan /atau jasa yang digunakan untuk memproduksi barang dan /jasa lain dengan tujuan mendapatkan keuntungan.

2. Konsumen antara (intermediate consumer), adalah setiap orang yang mendapatkan barang dan/jasa yang digunakan untuk memperdagangkan kembali juga dengan tujuan mencari keuntungan.

3. Konsumen akhir (ultimate consummer/end), adalah setiap orang yang mendapatkan dan menggunakan barang dan/jasa untuk tujuan memenuhi kebutuhan kehidupan pribadi, keluarga, orang lain dan makhluk hidup lainnya dan tidak untuk diperdagangkan kembali atau menarik keuntungan kembali.

Di Indonesia, untuk melindungi kepentingan konsumen dalam mengkonsumsi barang dan/atau jasa, pemerintah telah mengeluarkan kebijakan tentang pengaturan hak-hak 
Hijawati, Peredaran Obat Illegal Ditinjau Dari Hukum Perlindungan Konsumen, Halaman 394-406

konsumen melalui undang-undang. dilindungi. Dan Undang-undang ini Pembentukan undang-undang ini bukan anti terhadap produsen tetapi merupakan bagian dari Implementasi sebagai negara kesejahteraan, karena undang-undang Dasar 1945 di samping sebagai konstitusi politik juga sebagai konstitusi ekonomi yang mengandung ide bagi negara kesejahteraan.

Intervensi pemerintah sangat dibutuhkan dalam pembangunan demi untuk menegakkan dan menetapkan peraturan perundang-undangan dalam bidang ekonomi. Hal ini pentingnya intervensi pemerintah terkait dengan perlindungan konsumen, yakni:

1. Dalam masyarakat modern, produsen menawarkan berbagai jenis produk yang diproduksi secara massal.

2. Hasil produksi dengan cara massal dan teknologi canggih potensial bagi munculnya resiko produk cacat, dan tidak memenuhi standar bahkan berbahaya yang dapat merugikan konsumen.

3. Hubungan antara konsumen dan produsen berada pada posisi yang tidak seimbang.

4. Adanya persaingan yang sempurna.

Dalam Undang-undang Nomor 8 Tahun 1999 tentang Perlindungan Konsumen, Pemerintah Indonesia mengatur hak-hak konsumen yang harus malah sebaliknya merupakan apresiasi terhadap hak-hak konsumen secara universal. Karena perlindungan konsumen adalah merupakan bagian dari perlindungan hak asasi manusia. Perlindungan konsumen berlaku pada semua produk baik barang dan jasa, termasuk juga perlindungan dari peredaran obat illegal.

Dengan Undang-undang Republik Indonesia Nomor 8 Tahun 1999 Tentang Perlindungan Konsumen bertujuan untuk mewujudkan suatu masyarakat adil dan makmur yang merata materiil dan spiritual dalam era demokrasi ekonomi berdasarkan Pancasila dan Undang-Undang Dasar 1945. Pembangunan perekonomian nasional pada era globalisasi harus dapat mendukung tumbuhnya dunia usaha sehingga mampu menghasilkan beraneka barang dan/atau jasa yang memiliki kandungan teknologi yang dapat meningkatkan kesejahteraan masyarakat banyak dan sekaligus mendapatkan kepastian atas barang dan/atau jasa yang diperoleh dari perdagangan tanpa mengakibatkan kerugian konsumen. 
Hijawati, Peredaran Obat Illegal Ditinjau Dari Hukum Perlindungan Konsumen, Halaman 394-406

KESIMPULAN DAN

REKOMENDASI

Obat merupakan obat yang diproduksi oleh yang tidak berhak berdasarkan peraturan per-undang undangan yang berlaku dengan penandaan yang meniru identitas obat lain yang telah memiliki izin edar. Obat illegal adalah obat impor yang tidak terdaftar di Badan POM sehingga tidak mempunyai izin edar di Indonesia. Undang-undang Nomor 8 Tahun 1999 tentang Perlindungan Konsumen, Pemerintah Indonesia mengatur hak-hak konsumen yang harus dilindungi termasuk dalam perlindungan terhadap peredaran obat palsu maupun obat illegal. Karena perlindungan konsumen adalah merupakan bagian dari perlindungan hak asasi manusia.

$$
\text { Pemerintah hendaknya }
$$

bersungguh-sungguh dalam mengatasi setiap pelanggaran yang dilakukan oleh produsen yang tidak taat peraturan, terutama pada produk obat-obatan yang tidak memperhatikan atau mempertimbangkan akibatnya. Sangat berbahaya bila peredaran obat illegal terus terjadi, bukan hanya merugikan masyarakat atas jaminan mutu obat tersebut, tapi juga menyangkut kesehatan dan keselamatan jiwa dari penggunannya (konsumen).

\section{DAFTAR PUSTAKA}

Gunawan Wijaya dan Ahmad Yani. Hukum Perlindungan Konsumen. Jakarta: PT. Gramedia Pustaka Utama, 2003.

https://www.pom.go.id/new/admin/dat/2 0190708/Direktorat Pengamanan .pdf, 2020.

https://www.pom.go.id/new/admin/dat/2 0190708/Direktorat Pengamanan .pdf, 2020.

https://www.hukumonline.com/berita/ba ca/lt57d1345b3ed21/4-sebabperedaran-obat-ilegal-masihmarak/, 2020.

Sri Praptianingsih. Kedudukan Hukum perawat Dalam Upaya Pelayanan Kesehatan di Rumah Sakit. Jakarta: Raja Grafindo Persada, 2006.

Wila Chandrawila Supriadi, Hukum Kedokteran. Bandung: Mandar Maju, 2001.

WJS. Poerwadarminta, Kamus Umum Bahasa Indonesia. Jakarta: Balai Pustaka, 1999. 